\title{
PENGARUH PENYULUHAN KESEHATAN TERHADAP PENGETAHUAN IBU DALAM UPAYA PENCEGAHAN DEMAM BERDARAH DENGUE DI KELURAHAN PUNGGOLAKA KECAMATAN PUUWATU KOTA KENDARI
}

\author{
Irma ${ }^{1}$ Yusuf Sabilu² ${ }^{2}$ Lymbran Tina ${ }^{3}$ Febriana Muchtar ${ }^{4}$ \\ 1,2,3,4 Fakultas Kesehatan Masyarakat Universitas Halu Oleo \\ 1irmankedtrop15l@uho.ac.id'2yusufsabilu@yahoo.com3lymbranizzah@gmail.com \\ ${ }^{4}$ Febrianamuchtar9@uho.i.id
}

\begin{abstract}
Abstrak
Penyakit DBD sebagai salah satu penyakit menular yang disebabkan oleh virus dengue. Kota Kendari merupakan daerah yang endemik DBD dengan CFR 0,11 \% pada tahun 2014 dan Incidence Rate 152 per 1000 penduduk dan sebaran penyakit DBD di Kelurahan Punggolaka pada tahun 2015 sepanjang periode januari sampai Juni sebanyak 3 kasus. Penelitian ini merupakan jenis penelitian kuantitatif dengan desain pra-experimental onegroup pretest-posttest. Populasi dalam penelitian ini adalah semua keluarga yang ada dan tinggal di Kelurahan Punggolaka Kecamatan Puuwatu Kota Kendari sebanyak $1.473 \mathrm{KK}$ dan sampel dalam penelitian ini adalah ibu - ibu yang tinggal di Kelurahan Punggolaka sebanyak 104 orang yang diambil dengan teknik cluster random sampling. Uji statistik yang digunakan adalah McNemar dengan tingkat kepercayaan 95\%. Hasil penelitian menunjukkan bahwa pengetahuan ibu tentang pencegahan DBD sebelum pemberian penyuluhan kesehatan sebagian besar atau 77,9\% adalah kurang dan hanya $22,1 \%$ dengan kategori baik sedangkan pengetahuan ibu tentang pencegahan DBD sesudah pemberian penyuluhan kesehatan sebagian besar atau 72,1 \% menjadi baik dan hanya 29,7 \% dengan kategori kurang. Hasil analisis juga menunjukkan bahwa ada pengaruh yang signifikan pemberian penyuluhan kesehatan terhadap pengetahuan ibu tentang pencegahan DBD yang dibuktikan dengan nilai $p=0,001<$ nilai $\alpha=$ $0,05)$.
\end{abstract}

Kata kunci: penyuluhan kesehatan, DBD, masyarakat.

\begin{abstract}
Dengue Blood Fever (DBF) is one of communicable diseases which is caused by a dengue virus. Kendari city is endemic of DBF with $0.11 \%$ of CFR in 2014, and incidence rate was 152 per 1000 people, and distribution of DBF disease in Punggolaka Village was 3 cases of period of January to June 2015.This study was a quatitative study with a Pre-experimental One-group Pre-post test. The population of this study were all families who lived in Punggolaka Vilaage of Puuwatu Sub-District Kendari city, namely 1.473 households for less than 2 years and the numbers of samples were 104 people who were selected through a cluster random sampling technique. The statistical test used MCNemar with $95 \%$ of the confidence level. The results showed that the mother's knowledge about the DBF care before giving health promotion was $77.9 \%$, this meant less and $22.1 \%$ off good category. While the mother's knowlwdge about DHF care after giving health promotions showed $72.1 \%$ of the good category and only $29.7 \%$ off less category. The analytical test also showed that there was a signivicant effect of giving health promotion on mother's knowledge about the DBF care with $p$-value $=0,001<\alpha=0,05$.
\end{abstract}

Keywords: health promotion, DHF, public. 


\section{PENDAHULUAN}

Program pencegahan dan pemberantasan penyakit merupakan salah satu strategi Departemen Kesehatan yang bertujuan untuk menurunkan angka kesakitan, kematian dan kecatatan akibat penyakit menular dan penyakit tidak menular. Penyakit Demam Berdarah Dengue (DBD) atau Dengue Hemorrhagic Fever (DHF) merupakan salah penyakit menular dalam program pencegahan dan pemberantasan penyakit ${ }^{1,2}$.

DBD merupkan masalah kesehatan yang jumlah penderitanya dari tahun ketahun terus meningkat serta penyebaranya semakin meluas. Penyakit menular ini cenderung menyerang anakanak. DBD merupakan suatu penyakit endemik akut yang disebabkan oleh virus Dengue yang ditransmisikan oleh nyamuk Aedes Aegypti di daerah perkotaan dan nyamuk Aedes Abopictus di daerah pedesaan. Dengue adalah infeksi nyamuk yang ditemukan di daerah tropis dan subtropics di seluruh dunia. ${ }^{2,3}$

World Health Organization (WHO) melaporkan bahwa kasus DBD di di dunia terus meningkat dari 2,2 juta pada tahun 2010 menjadi lebih dari 3,34 juta pada tahun 2016 dan terjadi Kejadian Luar Biasa (KLB) di berbagai wilayah di dunia khususnya pada negara - negara tropis. Wilayah Amerika melaporkan lebih dari 2,38 juta kasus pada tahun 2016, Brasil dengan kasus kurang dari 1,5 juta kasus, sekitar 3 kali lebih tinggi dari tahun 2014. 1032 kematian dengue juga dilaporkan di wilayah tersebut. Wilayah Pasifik Barat melaporkan lebih dari 375.000 kasus dugaan demam berdarah pada tahun 2016, di mana Filipina melaporkan 176.411 dan Malaysia 100.028 kasus, mewakili beban yang sama dengan tahun sebelumnya untuk kedua negara. Kepulauan Solomon mengumumkan wabah dengan lebih dari 7000 tersangka. Di Wilayah Afrika, Burkina Faso melaporkan wabah demam berdarah setempat dengan kemungkinan 1061 kasus. Pada 2017, pengurangan signifikan dilaporkan dalam jumlah kasus demam berdarah di Amerika dari 2.177.171 kasus pada 2016 menjadi 584.263 kasus pada 2017 sehingga pengurangan $73 \%$. Panama, Peru, dan Aruba adalah satu-satunya negara yang mencatat peningkatan kasus selama 2017. Demikian pula, penurunan $53 \%$ dalam kasus demam berdarah juga dicatat selama $2017^{3}$.

Kementerian Kesehatan Republik Indonesia (Kemenkes RI) melaporkan bahwa kasus DBD di Indonesia mengalami fluaktuatif dimana pada tahun 2016 sebanyak 204.171 dan Insidence Rate (IR) sebesar 78,85 per 100.000 serta kematian sebesar 1598 kasus atau CFR sebesar 0,78\% dan pata tahun 2017 jumlah kasus DBD secara nasional turun menjadi 68.407 kasus dengan Incidence Rate sebesar
26,12 per 100.000 penduduk serta kematian sebesar 493 kasus atau CFR sebesar 0,72\%. Sedangkan jumlah kasus DBD pada tahun 2018 dilaporkan berjumlah 65.602 kasus dengan Incidence Rate sebesar 25,11 per 100.000 dengan jumlah kematian sebanyak 467 orang atau CFR sebesar 0,71\%. Dari data jumlah kasus secara nasional memang terjadi penurunan kasus yang cukup signifikan namun penurunan jumlah kasus signifikakn tidak dikuti oleh penurunan angka kematian yang bearti, oleh karena itu penyakit DBD masih merupakan penyakit yang cukup serius dan berisiko menimbulkan kematian ${ }^{4}$.

Kasus DBD juga telah menyebar di beberapa daerah kabupaten/kota di Provinsi Sulawesi Tenggara dan pada tahun 2016 jumlah kasus DBD di Sulawesi Tenggara sebanyak 3.433 dengan CFR sebesar 0,96\% dan jumlah DBD menurun pada tahun 2017 menjadi 817, akan tetapi dari sisi CFR justru terjadi peningkatan menjadi 1,4 . Sedangkan jumlah kasus pada tahun 2018 sebanyak 655 kasus dengan CFR sebesar 0,76. Kasus DBD di provinsi Sulawesi Tenggara kembali meningkat pada tahun 2019 yaitu sebanyak 1.493 kasus dengan CFR turun menjadi $0,6 \%$. turun 6

Data dari Dinas Kesehatan Kota Kendari menunjukkan bahwa jumlah kasus DBD Di Kota Kendari pada tahun 2019 berjumlah 450 kasus dengan CFR 0,4\% jumlah kasus tersebut meningkat dari tahun sebelumnya, yaitu 111 kasus dan tidak ada kematian. Incidence Rate DBD tahun 2019 meningkat secara signifikan dibandingkan tahun 2018, yaitu dari 29,94 per 100.000 penduduk menjadi 117,92 per 100.000 penduduk. Kasus kematian DBD yang terjadi pada tahun 2019 ada di wilayah kecamatan Puwatu kelurahan Punggolaka. Kematian in dapat dipengaruhi karena kuranganya pengetahuan dan kesadaran masyarakat terhadap penyakit DBD, olehnya itu menjadi penting dilaksanakannya program penyuluhan kesehatan pada masyarakat terutama pada daerah endemis DBD seperti kelurahan Punggolaka ${ }^{8}$

\section{METODE}

Penelitian ini merupakan jenis penelitian kuantitatif dengan desain pra-experimental onegroup pretest-posttest. One-group pretest-posttest merupakan rancangan penelitian yang tidak memiliki kelompok pembanding (kontrol) tetapi dilakukan observasi pertama (pretest) yang memungkinkan untuk menguji perubahan setelah dilakukan perlakuan (posttest). Tujuan penelitian ini adalah untuk mengetahui adanya pengaruh penyuluhan tentang pencegahan $\mathrm{DBD}^{7}$

Pengukuran yang dilakukan sebelum intervensi (01) disebut pretest. Pada penelitian ini pretest bertujuan untuk menetahui pengetahuan 
sebelum dilakukan intervensi $(\mathrm{X})$. Intervensi yang dilakukan adalah berupa penyuluhan kesehatan tentang konsep dasar DBD yang meliputi pengertian, penyebab dan gejala klinis. Setelah dilakukan perlakuan peneliti mengobservasi kembali pengetahuan (O2) yang disebut posttest. ${ }^{7}$

Populasi dalam penelitian ini adalah semua keluarga yang ada dan tinggal di Kelurahan Ponggolaka Kecamatan Puwatu Kota sebanyak 1.473 KK dan sampel dalam penelitian ini sebanyak 94 yang dihitung berdasarkan rumus $n=\frac{Z \alpha^{2} \cdot P \cdot Q}{d}$ dengan teknik penarikan sampel dalam penelitian ini adalah teknik randomisasi yaitu dengan teknik cluster random sampling. Instrumen penelitian yang digunakan adalah kuesioner dan data yang sudah terkumpul selanjutnya dianalisis secara bertahap yaitu analisis univariat dilakukan untuk mendapatkan gambaran tentang distribusi frekuensi variabel bebas yaitu penyuluhan kesehatan tentang penyakit DBD dan variabel terikat tingkat pengetahuan keluarga dan analisis bivariat digunakan untuk melihat pengaruh pemberian penyuluhan kesehatan terhadap pengetahuan keluarga dalam upaya pencegahan DBD di Kelurahan Ponggolaka Kecamatan Puwatu Kota Kendari dengan menggunakan analisis statistik McNemar. ${ }^{8,9}$

\section{HASIL DAN DISKUSI}

Tabel 1 Distribusi Frekuensi Karakteristik Responden Menurut Umur, Jenis Kelamin, Pendidikan dan ekerjaan di Kelurahan Punggolaka Kecamatan Puuwatu Kota Kendari Tahun 2019

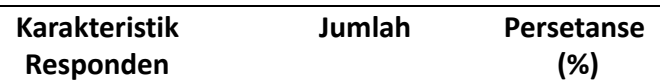

\begin{tabular}{lcc}
\hline Umur : & & \\
\hline \multicolumn{1}{c}{$21-30$ Tahun } & 39 & 37.50 \\
\hline \multicolumn{1}{c}{ 41-40 Tahun } & 43 & 41.35 \\
\hline \multicolumn{1}{c}{$>$} & 21 & 20.19 \\
\hline Jenis Kelamin: & 1 & 0,96 \\
\hline Laki - Laki & & \\
\hline Perempuan & 46 & 44,23 \\
\hline Tingkat Pendidikan : & 58 & 55,77 \\
\hline SMP & 16 & 15.38 \\
\hline SMA/Sederajat & 61 & 58,66 \\
\hline DIII/Diploma & 11 & 10,58 \\
\hline S1/Sarjana & 16 & 15.38 \\
\hline Pekerjaan : & & \\
\hline lbu Rumah Tangga & 57 & 54.81 \\
\hline Wiraswasta & 33 & 31.73 \\
\hline PNS & 14 & 13.46 \\
\hline
\end{tabular}

Tabel 1 menunjukkan bahwa dari 104 responden, terbanyak adalah kelompok umur 31 40 tahun yaitu sebanyak 43 orang $(41,35 \%)$ dan kelompok umur terkecil adalah umur $>51$ tahun yaitu sebanyak 1 responden (0,96\%). Dari karakter jenis kelamin sebanyak 58 orang $(55,77 \%)$ merupakan laki - laki dan sebanyak 46 orang $(44,23 \%)$ perempuan, dari karakter tingkat pendidikan sebagian besar responden yaitu 61 orang $(58,66 \%)$ adalah berpendidikan SMA/Sederajat dan hanya sebagian kecil responden yang memiliki tingkat pendidikan DIII/Diploma yaitu 11 orang $(10,58 \%)$, sedangkan dari karakter jenis pekerjaan sebagian besar responden yaitu sebanyak 57 orang $(54,80 \%)$ adalah Ibu Rumah Tangga (IRT) dan sebagian kecil yaitu sebanyak 14 orang $(13,5 \%)$ adalah PNS.

\section{Analisis Univariat}

Distribusi Frekuensi Pengetahuan Sebelum dan

\section{Sesudah Penyukuhan}

Distribusi responden menurut pengetahuan tentang pencegahan DBD sebelum penyuluhan dapat dilihat pada table 5 di bawah ini :

Tabel 2. Distribusi Frekuensi Responden Menurut Tingkat Pengetahuan Sebelum dan Sesudah Penyuluhan Di Kelurahan Punggolaka Kecamatan Puuwatu Kota Kendari Tahun 2019

\begin{tabular}{lcccc}
\hline \multirow{2}{*}{ Pengetahuan } & \multicolumn{2}{c}{$\begin{array}{c}\text { Sebelum } \\
\text { Penyuluhan }\end{array}$} & \multicolumn{2}{c}{$\begin{array}{c}\text { Sesudah } \\
\text { Penyuluhan }\end{array}$} \\
\cline { 2 - 5 } & $\mathbf{n}$ & $\mathbf{\%}$ & $\mathbf{n}$ & \% \\
\hline Baik & 23 & 22.11 & 75 & 72.1 \\
\hline Kurang & 81 & 77.99 & 29 & 27.9 \\
\hline Total & $\mathbf{1 0 4}$ & $\mathbf{1 0 0}$ & $\mathbf{1 0 4}$ & $\mathbf{1 0 0}$ \\
\hline
\end{tabular}

Tabel 2 menunjukkan bahwa tingkat pengetahuan sebelum penyuluhan dari 104 responden sebagian besar memiliki pengetahuan yang kurang pencegahan penyakit DBD yaitu sebanyak 81 orang $(77,99 \%)$ dan sebagaian keccil yaitu sebanyak 23 orang $(22,11 \%)$ responden dengan pengetahuan yang baik tentang pencegahan penyakit DBD. Sedangkan tingkat pengetahuan sesudah penyuluhan dari 104 responden sebagian besar yaitu 75 orang $(72,10 \%)$ responden memilki tingkat pengetahuan dengan kategori baik dan hanya sebagian kecil yaitu 29 orang (27,9\%) responden memiliki pengetahuan dengan kategori kurang.

Proses penyuluhan adalah merupakan proses untuk menambah pengetahuan dan kemampuan seseorang melalui tehnik praktek belajar atau instruksi dengan tujuan mengubah atau mempengaruhi perilaku manusia secara individu, kelompok maupun masyarakat untuk dapat lebih mandiri dalam mencapai tujuan hidup sehat ${ }^{10}$ 
Hasil analisis univariat pada penelitian ini menunjukkan bahwa tingkat pengetahuan ibu tentang pencegahan penyakit DBD sebelum penyuluhan sebagian besar atau sebanyak 81 orang $(77,9 \%)$ adalah tergolong kurang dan hanya sebesar 23 orang ( $22,1 \%$ ) responden dengan pengetahuan yang baik tentang pencegahan penyakit DBD. Hal ini dapat dipahami karena sebagian besar atau sebanyak 61 orang $(58,7 \%)$ responden memiliki latar belakang pendidikan setingkat SMA sederajat. Seperti halnya penelitian yang pernah dilakukan oleh Bonita (2007) yang menemukan bahwa sebesar 68,2 responden memiliki pengetahuan yang rendah tentang pencegahan penyakit DBD sebelum intervensi penyuluhan. Hasil penelitian ini juga didukung oleh teori Notoatmodjo (2011) yang mngatakan bahwa salah satu cara untuk merubah atau meningkatkan penegtahuan masyarakat tentang sebuah konsep hidup sehat adalah dengan penyuluhan.

\section{Analisis Bivariat}

Hasil analisis bivariat untuk melihat ada tidaknya pengaruh penyuluhan terhadap pengetahuan masyarakat dalam pencegahan penyakit DBD dapat dilihat pada tabel 3 berikut ini :

Tabel 3. Pengaruh Pemberian Penyuluhan Kesehatan Terhadap Pengetahuan Masyrakat Dalam Pencegahan Penyakit Demam Berdarah Dengue Di Kelurahan Punggolaka Kecamatan Puuwatu Kota Kendari Tahun 2019

\begin{tabular}{|c|c|c|c|c|c|}
\hline & & \multicolumn{2}{|c|}{ Pengetahuan Sesudah Penyuluhan } & \multirow[t]{2}{*}{ Total } & \multirow[t]{2}{*}{ Nilai p } \\
\hline & & Baik & Kurang & & \\
\hline Pengetahuan Sebelum & Baik & 21 & 2 & 23 & 0,001 \\
\hline Penyuluhan & Kurang & 54 & 27 & 81 & \\
\hline Total & & 75 & 29 & 104 & \\
\hline
\end{tabular}

Tabel 3 menunjukkan bahwa ada perbedaan pengetahuan responden tentang pencegahan penyakit DBD sebelum penyuluhan hanya sebesar hanya sebesar 23 orang (22,12\%) dan sesudah penyuluhan mengalami peningkatan menjadi 75 orang $(72,12 \%)$.

Hasil uji statistik dengan menggunakan uji McNemar diperoleh nilai $p=0,001$ dan nilai $\alpha=0,05$. Karena nilai $\rho(0,001)<$ nilai $\alpha(0,05)$ maka Ho ditolak, yang berarti bahwa ada pengaruh pemberian penyuluhan kesehatan terhadap pengetahuan ibu tentang pencegahan penyakit DBD di Kelurahan Punggolaka Kecamatan Puuwatu Kota Kendari.

Hasil penelitian ini juga menunjukkan bahwa ada pengaruh yang signifikan antara pemberian penyuluhan terhadap tingkat pengetahauan ibu tentang pencegahan DBD. Hal ini dibuktikan dengan hasil analisis statistik dengan uji McNemar diperoleh nilai $p=0,001<$ nilai $\alpha=0,05$. Perubahan tingkat pengetahuan ibu tentang pencegahan penyakit DBD sesudah pemberian penyuluhan kesehatan yang cukup besar. Ini disebabkan karena ibu - ibu yang menjadi responden saat penelitian sangat antusias dan memperhatikan materi penyuluhan, oleh karena meraka merasa dan sadar bahwa seorang Ibu adalah merupakan orang tua yang paling dekat dengan seorang anak terutama bagi anak balita mereka. Selain itu responden juga sebagian merupakan orang tua dari penderita DBD yang pernah dirawat di rumah sakit sehingga mereka sudah pernah terpapar informasi tentang penyakit DBD.

Hasil penelitian ini sesua dengan hasil penelitian dari Sungkar et all (2010) yang menunjukkan bahwa pengetahuan reponden anak usia sekolah dasar tentang pencegahan dan perawtan pada penyakit DBD lebih tinggi sesudah intervensi penyuluhan dibandingkan dengan pengetahuan sebelum intervensi penyuluhan ${ }^{11}$.

Hal lain yang memungkin adanya pengaruh yang cukup signifikan antara pemberian penyuluhan kesehatan terhadap pengetahuan ibu - ibu responden adalah karena mereka sebelumnya sudah pernah mendapatkan informasi mengenai penyakit DBD. Seperti yang dikemukakan oleh Simamora (2009) yang menyatakan bahwa seseorang yang sudah pernah mendapat informasi tentang topik atau materi penyuluhan yang disampaikan, orang tersebut akan memudah diriya dalam memahami dan mengadopsi sebuah konsep yang disampaikan ${ }^{12}$.

Pengetahuan merupakan faktor penting yang mempengaruhi sikap, perilaku dan tindakan dari seseorang. Tentu saja dengan pengetahuan yang dimiliki seseorang dapat merubah pola pikir, sikap dan perilakukanya termasuk perilaku atau tindakan dalam upaya pencegahan suatu penyakit seperti DBD. Kurangnya pengetahuan dapat berpengaruh pada tindakan yang dilakukan karena pengetahuan merupakan salah satu faktor predisposisi untuk terjadinya perilaku atau tindakan. Oleh karena itu untuk mendidik masyarakat agar mempunyai perilaku yang baik, warga perlu diberikan pengetahuan seperti program penyuluhan. Hal ini merupakan dasar sehingga ada pengaruh posisti program atau kegiatan penyuluhan dengan upaya pencegahan DBD, termasuk dalam penelitian ini $^{15}$. 


\section{SIMPULAN DAN SARAN}

Pengetahuan masyarakat tentang pencegahan penyakit DBD sebelum pemberian penyuluhan kesehatan dengan kategori baik hanya sebesar 22,1\% dan mengalami peningkatan yang signifikan setelah pemberian penyuluhan yaitu $72,1 \%$ dengan kategori baik sehingga dapat disimpulkan bahwa ada pengaruh yang signifikan antara pemberian penyuluhan kesehatan terhadap pengetahuan masyarakat pencegahan penyakit DBD di Kelurahan Punggolaka Kecamatan Puuwatu Kota Kendari. Oleh karena itu bagi instansi kesehatan dalam hal ini Dinas Kesehatan atau Puskesmas yang ada di Kota Kendari penting untuk selalu menjalankan program promosi kesehatan dalam hal ini pencegahan penyakit melular termasuk pencegahan penyakit DBD yang yang selalu menimbulkan KLB dan korban jiwa.

\section{DAFTAR PUSTAKA}

1. Suryani ET. Gambaran Kasus Demam Berdarah Dengue Di Kota Blitar Tahun 2015-2017 [Internet]. Jakarta; 2018. 260-267. p. Available from: https://doi.org/10.20473/jbe.v6i3

2. Prasetyowati A, Kushartanti R. Dengue Di Wilayah Kerja Puskesmas Rowosari. 2019;02(November):23-9.

3. Hijroh, Bahar H, Ismail CS. Perilaku Masyarakat Dalam Mencegah Penyakit Demam Berdarah Dengue (DBD) Puskesmas Puuwatu Kota Kendari Tahun 2017. JIMKESMAS. 2017;2(6):1-9.

4. Yudhastuti R, Lusno MFD. Gambaran Kasus Demam Berdarah Dengue (DBD) Di Pulau Bali Tahun 2012-2017. J Kesehat Lingkung Indones. 2020;19(1):27.

5. WHO. Dengue and Severe Dengue. 2019; Available from: https://www.who.int/newsroom/fact-sheets/detail/dengue-and-severedengue

6. Kementerian Kesehatan RI. InfoDatin Situas Demam Berdarah Dengue [Internet]. Vol. 31, Journal of Vector Ecology. 2018. p. 71-8. Available from:

https://www.kemkes.go.id/download.php?file=d ownload/pusdatin/infodatin/InfoDatin-SituasiDemam-Berdarah-Dengue.pdf

7. Sultra DKP. Laporan Bidang Pencegahan dan Pengendalaian Penyakit Dinas Kesehatan Provinsi Sulawesi Tenggara. 2019;27-35.

8. Dinkes Kota Kendari. Profil Dinas Kesehatan Kota Kendari Tahun 2019. 2020;54-67.

9. Nasir A. MA dan IM. Buku Ajar: Metodologi Penelitian Kesehatan Konsep Pembuatan Karya Tulis dan Tesis Untuk Mahasiswa Kesehatan. [Internet]. Yogyakarta: Nuha Medika; 2011. 170-
180 p. Available from: http:// www. nuhamedika.gu.ma

10. Murti B. Desain dan Ukuran Sampel Untuk Penelitian Kuantitatif dan Kualitatif di Bidang Kesehatan. Yogyakarta: Gadjah Mada University Press; 2006. 110-115 p.

11. Dahlan MS. Statistik Untuk Kedokteran dan Kesehatan. Jakarta: Salemba Medika; 2011. 40$45 \mathrm{p}$.

12. Resmiati R, Cita YP, Susila A. Pengaruh Penyuluhan Demam Berdarah Terhadap Perilaku Ibu Rumah Tangga. Kesmas Natl Public Heal J. 2009;3(6):249.

13. Sungkar S, Winita R, Kurniawan A. The Effect of Health Education to Community Knowledge and Aedes aegypti Density in Bayah Subdistrict, Banten Province. Makara J Heal Res. 2011;14(2):1-6.

14. Hadi C, Sugiarto, K.Y M, Rahmah Z. Pengaruh Penyuluhan Kesehatan dengan Media Komik Tanggap DBD Terhadap Peningkatan Pengetahuan dan Sikap Tentang Pencegahan DBD di SDN Banjarejo Ngadiluwih Kabupaten Kediri. Pros Semnas Compet. 2012;1(2).

15. Kusumawardani E, Arkhaesi N, Hardian H. Pengaruh Penyuluhan Kesehatan Terhadap Tingkat Pengetahuan, Sikap Dan Praktik Ibu Dalam Pencegahan Demam Berdarah Dengue Pada Anak. J Kedokt Diponegoro. 2012;1(1):104456. 